\title{
Nutritive Value of Sitosterol for the Prawn Penaeus japonicus
}

\author{
Shin-ichi Teshima, ${ }^{*}$ Akio Kanazawa,* Shunsuke Koshio,* \\ and Nobuhiro Kondo* \\ (Received August 1, 1988)
}

\begin{abstract}
The larval and juvenile prawns Penaeus japonicus were maintained on purified diets with cholesterol alone and mixtures of cholesterol-sitosterol $(1: 1,1: 3,1: 10,1: 30,1: 100)$ to evaluate a cholesterol-sparing effect of sitosterol. The juvenile prawns had the highest weight gain (\%), feed conversion efficiency (FCE) and protein efficiency ratio (PER) on the diet containing $0.5 \%$ cholesterol alone. The partial replacement of cholesterol with sitosterol reduced the weight gain, FCE, and PER inversely with increasing proportions of sitosterol. The body retention rates (\%) of dietary proteins, lipids, total sterols, and cholesterol were lowered when dietary cholesterol was partially replaced with sitosterol. The larval prawns also grew best with the highest survival rate on the diet containing $1.0 \%$ cholesterol alone. The partial replacement of cholesterol with sitosterol (cholesterol/sitosterol ratios of $1: 1,1: 3,1: 10$, and 1:30) did not decrease the survival rates markedly but slightly retarded the larval development with increasing proportions of sitosterol. These results indicated that sitosterol had the cholesterol-sparing effect in terms of survival rates for the larvae but not for the juveniles, suggesting the change in sterol metabolism during the life cycle of the prawn.
\end{abstract}

In an earlier study, we demonstrated that the prawn Penaeus japonicus required a dietary source of sterols for normal growth. ${ }^{1)}$ Later, several groups of workers confirmed the necessity of including sterols in diets for the growth of the prawn $^{2,3)}$ and Artemesia longinaris, ${ }^{4)}$ the lobster, Homarus americanus ${ }^{5)}$ and hybrids ( $H$. americanus $\times H$. gammarus $; H$. gammarus $\times H$. americanus $),{ }^{6)}$ and the crab Carcinus maenas. ${ }^{7)} \mathrm{We}^{3,8)}$ previously showed that although cholesterol had the highest nutritive value for the prawn, some phytosterols such as 24-methylcholesta-5, 22-dienol, sitosterol, etc. were effective to some extent as sterol sources. Whereas, D'Abramo et al, ${ }^{6)}$ reported that total replacement of cholesterol with a mixture of phytosterol consisting mainly of sitosterol and campesterol did not adequately substitute for cholesterol in a diet for juvenile lobsters.

In our previous study, ${ }^{8)}$ it seemed likely that the addition of small amounts of cholesterol to a prawn diet containing sitosterol slightly improved the feed conversion efficiency (FCE) and protein efficiency ratio (PER) but did not the weight gain $(\%)$. This suggests the possibility that sitosterol spares the requirement of cholesterol in $P$. japonicus. The aim of the present study was to evaluate the cholesterol-sparing effect of sitosterol in prawns.
To approach this, feeding trials using purified diets were conducted with the larval and juvenile prawns.

\section{Materials and Methods}

\section{Feeding Trials Using the Juveniles}

The juvenile prawns were obtained from Matsumoto Suisan Co., Ltd. in Miyazaki Prefecture, transported to this laboratory, and maintained on a commercial prawn feed until use. The juveniles, weighing an average of $0.48 \mathrm{~g}$, were divided into lots of 20 prawns per $30 l$-aquarium, and then reared with test diets (Table 1) at $10 \%$ of their body weight twice a day $(2 \%$ at $9: 00$ a.m. and $8 \%$ at $5: 00$ p.m.) in a recirculating system for 4 weeks at $25 \pm 1^{\circ} \mathrm{C}$. The aquaria were covered with a black plastic sheet all day throughout the experimental period. The prawns were weighed at the beginning of feeding trials and every week, and the daily ration was adjusted after each weighing. The basal ration of test diets was the same as mentioned previously, ${ }^{8)}$ and the compositions of test diets were the same each other except for those of sterols and cellulose. Test diets were prepared by the same method as mentioned previously, ${ }^{83}$ but wet diets so obtaineed

* Faculty of Fisheries, University of Kagoshima, Shimoarata, Kagoshima 890, Japan (手島新一，金沢昭夫, 越塩伐介, 近藤伸広: 鹿児䒸大学水産学部)。 
Table 1. Composition of test diets for the juvenile prawns

\begin{tabular}{cl}
\hline Diet No.* & \multicolumn{1}{c}{ Sterol source } \\
\hline 1 & $0.5 \%$ Cholesterol \\
2 & $0.5 \%$ Cholesterol-Sitosterol $(1: 1)$ \\
3 & $0.5 \%$ Cholesterol-Sitosterol $(1: 3)$ \\
4 & $0.5 \%$ Cholesterol-Sitosterol $(1: 10)$ \\
5 & $0.5 \%$ Cholesterol-Sitosterol $(1: 30)$ \\
6 & $0.5 \%$ Cholesterol-Sitosterol $(1: 100)$ \\
\hline
\end{tabular}

* The basal ration of test diets was the same as reported previously and contained the following ingredients $(\mathrm{g} / 100 \mathrm{~g}$ diet): Casein, 50 ; glucose, 5.5 ; sucrose, $10.0 ; \alpha$-starch, 4.0 ; glucosamine $\mathrm{HCl}, 0.8 ; \mathrm{Na}$ citrate, $0.3 ; \mathrm{Na}$ succinate, 0.3 ; pollack liver oil, 6.0 ; soybean lecithin, 2.0 ; sterol, 0.5 ; mineral mixture, 8.6 ; vitamin mixture, 2.7; cellulose powder, 6.3; agar, 3.0. The pH value of diets was adjusted to 6.8 .

were then freeze-dried for $2 \mathrm{~h}$ to give dry diets (10-20\% moisture) and stored in a refrigerator until use.

The weight gain (\%), FCE, and PER of the juveniles were analysed by Student's $t$-test. ${ }^{\left.{ }^{*}\right)}$

\section{Feeding Trials Using the Larvae}

Zoea $_{1}$ larvae were obtained from egg-bearing females in August. Feeding experiments using the larvae were conducted with microparticulate diets containing carrageenan as a binder (carrageenan MBD). ${ }^{11}$ Zoea ${ }_{1}$ larvae were reared with test diets (Table 3) containing different sterols at a level of $1 \%$ under the conditions given in Table 2 . The basal ration of test diets was the same as reported previously. ${ }^{8)}$ The methods for preparing the diets and rearing the larvae were similar to those described previously. ${ }^{8)}$ The survival rates and larval stages of the larvae were determined on the basis of 10 random samples every day. All living larvae

Table 2. Rearing conditions of the larval prawns

\begin{tabular}{|c|c|}
\hline Remark & Condition \\
\hline Larvae used & Zoea $_{1}$ stage* \\
\hline $\begin{array}{l}\text { Number of larvae/tank } \\
\text { (1 } l)\end{array}$ & 200 \\
\hline Feeding period & 10 days (during August) \\
\hline Water temperature & $24 \pm 1^{\circ} \mathrm{C}$ \\
\hline Feeding frequency & $\begin{array}{l}\text { Twice a day }(9: 00 \text { and } \\
16: 00)\end{array}$ \\
\hline Particle size & $\begin{array}{l}\text { Zoea }_{1}-\text { Zoea }_{3} ; 53 \mu \mathrm{m} \\
\text { Mysis }_{1}-\text { Mysis }_{2} ; 125 \mu \mathrm{m} \\
\text { Mysis }_{3}-\text { Postlarva }_{1} ; 250 \mu \mathrm{m}\end{array}$ \\
\hline Feeding level & $\begin{array}{l}\text { Zoeal larvae; } \\
0.16 \mathrm{mg} / \mathrm{larva} / \text { day } \\
\text { Mysis larvae; } \\
0.20 \mathrm{mg} / \mathrm{larva} / \text { day }\end{array}$ \\
\hline
\end{tabular}

- Mother prawns were obtained from Matsumoto Suisan Co. in Miyazaki, and put into $500 l$ tanks for spawning.
Table 3. Composition of test diets for the larval prawns

\begin{tabular}{cl}
\hline Diet No.* & Sterol source \\
\hline $1 \mathrm{C}$ & $1 \%$ Cholesterol \\
$2 \mathrm{C}$ & $1 \%$ Cholesterol-Sitostcrol $(1: 1)$ \\
$3 \mathrm{C}$ & $1 \%$ Cholesterol-Sitosterol $(1: 3)$ \\
$4 \mathrm{C}$ & $1 \%$ Cholesterol-Sitosterol $(1: 10)$ \\
$5 \mathrm{C}$ & $1 \%$ Cholesterol-Sitosterol $(1: 30)$ \\
$6 \mathrm{C}$ & $1 \%$ Cholesterol-Sitosterol $(1: 100)$ \\
\hline
\end{tabular}

- The basal ration of test diets was the same as reported previously and contained the following ingredients $(\mathrm{g} / 100 \mathrm{~g})$ : Casein, 42.8; L-arginine $\mathrm{HCl}$, 2.41; glucose-sucrose- $\alpha$-starch (5.5: 10.0:4.0), 25.0; pollack liver oil, 6.0; soybean lecithin, 3.0; a mixture of $20: 5 \omega 3$ and $22: 6 \omega 3$ (about $3: 2$ ), 0.5 ; sterol, 1.0; glucosamine $\mathrm{HCl}, 0.8$; Na citrate, 0.3 ; Na succinate, 0.3 ; minerals, 8.6; vitamins, 3.0; cellulose powder, 6.29. To this, $5.0 \mathrm{~g}$ of $\kappa$-carrageenan was added as a binder. All test diets were isonitrogenous $(6.25 \times \mathrm{N}=40.5 \mathrm{~g} / 100 \mathrm{~g})$.

were counted and staged at the end of feeding trials in the similar manner mentioned previously. $\left.{ }^{8}, 10\right\rangle$ The survival and growth data of the larvae were evaluated by Chi-square test. ${ }^{11}$ )

\section{Chemical Analysis of the Prawns}

The juvenile prawns were analysed for moisture, protein, lipid, and sterol concentrations to evaluate the body retention $(\%)$ of these compounds as described previously. ${ }^{8}$ ) Individual sterol components were quantified by gas-liquid chromatography (GLC) on $1.5 \%$ OV-17 using $5 \alpha$-cholestane as an internal standard. ${ }^{12}$ )

\section{Results}

The juvenile prawns had the highest weight gain $(\%), \mathrm{FCE}$, and PER on diet 1 containing $0.5 \%$ cholesterol alone when fed the test diets containing $0.5 \%$ levels of various sterols such as cholesterol alone and mixture of cholesterolsitosterol $(1: 1,1: 3,1: 10,1: 30,1: 100)$ (Table 4). The partial replacements of cholesterol with sitosterol at a constant sterol level of $0.5 \%$ in diets (diets 2-6) significantly $(P<0.05)$ reduced the weight gain, FCE, and PER inversely with increasing proportions of sitosterol in the mixture of cholesterol and sitosterol (Table 4 and Fig. 1). Table 5 shows the moisture, protein, lipid, and sterol concentrations of the bodies of prawns before and after the feeding trial. The moisture, protein, and lipid concentrations of the bodies did not differ notably among the juveniles receiving different sterol sources. However, the total sterol and cholesterol concentrations of the bodies decreased when the juveniles fed diets containing $50 \%$ or more of sitosterol as a sterol source. In- 


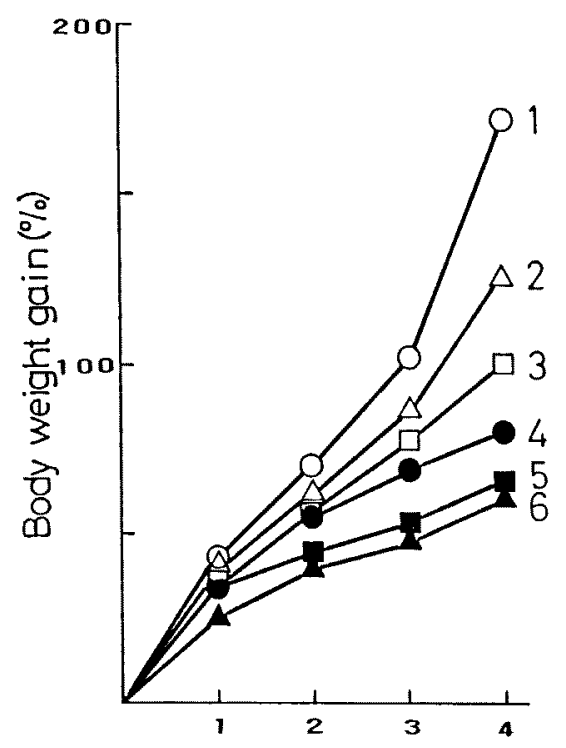

Feeding period (weeks)

Fig. 1. Growth of the prawn juveniles fed diets containing different proportions of cholesterol and sitosterol as a sterol source. Numbers indicate diet No. The ratios of cholesterol and sitosterol in diets were as follows; diet 1 , cholesterol alone; diet $2,1: 1$; diet $3,1: 3$; diet 4 , $1: 10$; diet $5,1: 30$; diet $6,1: 100$. terestingly, substantial amounts of 24-methylenecholesterol besides sitosterol were detected in the juveniles fed diets containing sitosterol. The body retention rates $(\%)$ of dietary proteins, lipids, total sterols, and cholesterol were lowered in every group of the juveniles when dietary cholesterol was partially replaced with sitosterol (Table 6). Except for the juveniles fed diets 5 and 6 containing small amounts of cholesterol, the body retention rates of dietary cholesterol were higher than those of dieatry sitosterol.

As for the larvae, the feeding trial was conducted using the microparticulate diets containing $1.0 \%$ of various sterols. The larvae receiving $1 \%$ cholesterol alone (diet $1 \mathrm{C}$ ) as sterol sources grew up to post-larva ${ }_{1}$ in 10 days (Table 7). The growth index of diet $2 \mathrm{C}$ containing $1 \%$ cholesterolsitosterol $(1: 1)$ was not significantly $(\mathrm{P}<0.05)$ different from that of diet $1 \mathrm{C}$. The replacement of more than $50 \%$ of cholesterol with sitosterol (diets $3 \mathrm{C}-6 \mathrm{C}$ ) resulted in the retardation of larval development $(\mathrm{P}<0.05)$. Whereas, the survival rates did not differ significantly $(\mathrm{P}<0.05)$ among the larvae groups receiving different sterols, although diet $6 \mathrm{C}$ containing $1 \%$ cholesterol-sitosterol $(1: 100)$ tended to give a slightly lower survival rate

Table 4. Growth of the juvenile prawns fed test diets for 4 weeks

\begin{tabular}{cccccccc}
\hline \hline $\begin{array}{l}\text { Diet } \\
\text { No. }\end{array}$ & $\begin{array}{c}\text { Survival } \\
\text { rate }(\%)^{* 1}\end{array}$ & \multicolumn{2}{c}{ Av. body wt. $(\mathrm{g})$} & $\begin{array}{c}\text { Diet con- } \\
\text { sumed }(\mathrm{g})^{* 2}\end{array}$ & $\begin{array}{c}\text { Weight } \\
\text { gain }(\%)\end{array}$ & $\begin{array}{c}\text { FCE } \\
(\%)\end{array}$ & PER \\
\hline 1 & 70 & $0.45 \pm 0.10$ & $1.22 \pm 0.30$ & 1.98 & 171 & 39 & 1.01 \\
2 & 100 & $0.48 \pm 0.10$ & $1.09 \pm 0.24$ & 1.85 & 127 & 33 & 0.86 \\
3 & 90 & $0.47 \pm 0.10$ & $0.94 \pm 0.23$ & 2.01 & 100 & 23 & 0.58 \\
4 & 100 & $0.49 \pm 0.09$ & $0.88 \pm 0.16$ & 1.73 & 80 & 23 & 0.52 \\
5 & 95 & $0.54 \pm 0.10$ & $0.89 \pm 0.18$ & 1.66 & 64 & 21 & 0.52 \\
6 & 100 & $0.48 \pm 0.10$ & $0.78 \pm 0.20$ & 1.73 & 62 & 17 & 0.41 \\
\hline
\end{tabular}

*1 Twenty prawns were held in each aquarium at the start of the feeding trial.

*2 Diet consumed (g)/one prawn.

Table 5. Protein, lipid, and sterol concentrations of the prawn bodies before and after feeding trials

\begin{tabular}{|c|c|c|c|c|c|c|c|}
\hline \multirow{3}{*}{ Remark } & \multirow{3}{*}{$\begin{array}{c}\text { Before } \\
\text { feeding } \\
\text { trial }\end{array}$} & \multicolumn{6}{|c|}{ After feeding trial } \\
\hline & & \multicolumn{6}{|c|}{ Diet No. } \\
\hline & & 1 & 2 & 3 & 4 & 5 & 6 \\
\hline Moisture $(\%)$ & 75.5 & 75.5 & 79.1 & 76.9 & 77.4 & 78.7 & 78.1 \\
\hline Protein $(\%$ dry wt.) & 69.6 & 63.6 & 65.0 & 66.2 & 63.8 & 64.8 & 65.4 \\
\hline Lipid (\% dry wt.) & 8.4 & 9.0 & 9.1 & 9.8 & 8.4 & 9.2 & 9.6 \\
\hline Sterols ( $\%$ dry wt.) & 2.58 & 2.49 & 2.17 & 2.14 & 1.75 & 1.87 & 1.29 \\
\hline Cholesterol & 2.58 & 2.49 & 2.04 & 2.02 & 1.64 & 1.77 & 1.22 \\
\hline 24-Methylenecholesterol & - & - & 0.04 & 0.02 & 0.01 & $\mathbf{t}^{*}$ & $\mathbf{t}^{*}$ \\
\hline Sitosterol & - & - & 0.09 & 0.10 & 0.10 & 0.10 & 0.07 \\
\hline
\end{tabular}

* Less than $0.01 \%$. 
Table 6. Effects of dietary sterols on the body retention rates (\%) of dietary proteins, lipids, and sterols in the juvenile prawns

\begin{tabular}{|c|c|c|c|c|c|c|}
\hline \multirow{3}{*}{ Compound } & \multicolumn{6}{|c|}{ Body retention $(\%)^{* 1}$} \\
\hline & \multicolumn{6}{|c|}{ Dietary sterol*2 } \\
\hline & $\mathrm{CH}$ & $\begin{array}{c}\text { CH-ST } \\
(1: 1)\end{array}$ & $\begin{array}{c}\text { CH-ST } \\
(1: 3)\end{array}$ & $\begin{array}{l}\text { CH-ST } \\
(1: 10)\end{array}$ & $\begin{array}{l}\text { CH-ST } \\
(1: 30) \\
\end{array}$ & $\begin{array}{r}\text { CH-ST } \\
(1: 100)\end{array}$ \\
\hline Crude protein & 12.7 & 7.7 & 7.1 & 5.5 & 4.2 & 3.8 \\
\hline Lipids except sterols & 22.2 & 14.8 & 14.7 & 9.7 & 9.7 & 9.5 \\
\hline Total sterols & 46.6 & 20.6 & 16.9 & 4.6 & 2.4 & -0.1 \\
\hline Cholesterol & 46.6 & 34.7 & 55.8 & 25.6 & 0 & -3.2 \\
\hline Sitosterol & 0 & 4.3 & 3.1 & 2.7 & 2.6 & 1.4 \\
\hline
\end{tabular}

*1 Body retention $(\%)=\mathrm{B} \times 100 / \mathrm{A} ; \mathrm{A}=$ intake (g) from diet, $\mathrm{B}=$ increase $(\mathrm{g})$ in the body during the feeding period.

*2 $\mathrm{CH}$, cholesterol; ST, sitosterol.

Table 7. Growth and survival of the larval prawns

\begin{tabular}{|c|c|c|c|c|c|c|c|c|}
\hline \multirow{3}{*}{$\begin{array}{l}\text { Diet } \\
\text { No. }\end{array}$} & \multirow{3}{*}{$\begin{array}{l}\text { Feeding } \\
\text { perid } \\
\text { (days) }\end{array}$} & \multirow{3}{*}{$\begin{array}{c}\text { Survival } \\
\text { rate } \\
(\%)\end{array}$} & \multicolumn{5}{|c|}{ Number of the prawns } & \multirow{3}{*}{$\begin{array}{l}\text { Growth } \\
\text { index* }\end{array}$} \\
\hline & & & \multicolumn{5}{|c|}{ Developmental stage } & \\
\hline & & & $Z_{1}-Z_{3}$ & $\mathbf{M}_{1}$ & $\mathrm{M}_{2}$ & $\mathbf{M}_{3}$ & $\mathbf{P}_{1}$ & \\
\hline 1 & 10 & 75 & 0 & 0 & 0 & 0 & 150 & 7.0 \\
\hline 2 & 10 & 75 & 0 & 0 & 0 & 60 & 90 & 6.6 \\
\hline 3 & 10 & 82 & 0 & 0 & 49 & 98 & 17 & 5.8 \\
\hline 4 & 10 & 77 & 0 & 0 & 8 & 138 & 8 & 6.0 \\
\hline 5 & 10 & 72 & 0 & 14 & 42 & 88 & 0 & 5.5 \\
\hline 6 & 10 & 61 & 0 & 0 & 48 & 74 & 0 & 5.6 \\
\hline
\end{tabular}

* Zoea $_{1}\left(Z_{1}\right), 1 ;$ zoea $_{2}\left(Z_{2}\right), 2 ;$ zoea $_{3}\left(Z_{8}\right) .3 ;$ mysis $_{1}\left(M_{1}\right), 4 ;$ mysis $_{2}\left(M_{2}\right), 5 ;$ mysis $_{3}\left(M_{3}\right), 6 ;$ post-larva $_{1}\left(P_{1}\right), 7$.

than the other groups (Table 7). When diets contained small amounts of cholesterol (not less than $0.032 \%$ in diets), the addition of sitosterol to diets was effective in sustaining the survival of the larvae as comparable to diets containing cholesterol alone. These results of the larvae indicated that sitosterol probably had a cholesterol-sparing effect to some extent, in terms of the survival rates.

\section{Discussion}

The results of the present study indicated that sitosterol had almost no cholesterol-sparing effect for the juveniles. The occurrence of 24-methylenecholesterol in the juveniles fed diets containing sitosterol suggests the possible intermediary role of 24-methylenecholesterol in the bioconversion of sitosterol to cholesterol in prawns. However, it should be more rigorously confirmed by tracer experiments that the dealkylation of sitosterol to cholesterol in the prawn proceeds via 24-methylenecholesterol or fucosterol-24, 28-epoxide as proposed in insects. ${ }^{13,14}$ The low body retention rates of sitosterol in prawn juvenile (Table 6) suggest that sitosterol, even if absorbed from the guts, is excreted faster from the body than chole- sterol, as also demonstrated previously in the metabolic studies of the prawn using radioactive sterols. ${ }^{15}$ ) These results indicate that sitosterol is probably utilized as a sterol source after being converted to cholesterol and the bioconversion may not proceed in a fast rate in $P$. japonicus juveniles. The irreplaceable cholesterol requirement in diets supplies a strict metabolic need for cholesterol as a precursor of steroid hormones ${ }^{18)}$ and possibly a constituent of cellular membranes ${ }^{17,18)}$ in this prawn.

Although the prawn larvae ${ }^{3)}$ were found to require higher levels of cholesterol in diets for their normal growth and survival than the juveniles, ${ }^{1,2}$ ) the present study showed that the larvae survived well as comparable to the cholesterol-diet (diet 1C) when reared with diets containing small amounts of cholesterol supplemented with sitosterol in the ratios of $1: 30,1: 10$, and $1: 3$, although the larval development was slightly retarded. In contrast to the juveniles, sitosterol was therefore likely to exert a slight cholesterol-sparing effect in the larvae, especially in terms of survival rates, suggesting the change in sterol metabolism during the life cycle of $P$. japonicus. In insects, the information shows that a large part of the 
normal cholesterol requirement can be spared by the addition of other sterols such as sitosterol, cholestanol, etc. which were ineffective as sterol sources. ${ }^{\left.1{ }^{1}\right)}$ Although the mechanism by which some sterols spare the dietary requirement for cholesterol in insects is not completely clear, ${ }^{20)}$ the most possible explanation is that mimimal cholesterol may satisfy a highly specific role in the tissues, whereas the sparing sterols fulfill a different structural role of less specificity. ${ }^{18,10)}$

Further work is required to clarify the structural role and turnover of various sterols in crustacean tissues.

\section{References}

1) A. Kanazawa, N. Tanaka, S. Teshima, and K. Kashiwada: Nippon Suisan Gakkaishi, 37, 10151019 (1972).

2) O. Deshimaru and K. Kuroki: Nippon Suisan Gakkaishi, 40, 421-424 (1974).

3) S. Teshima, A. Kanazawa, and H. Sasada: Aquaculture, 31, 159-167 (1983).

4) A. M. Petriela, M. I. Muller, J. L. Fenucci, and M. B. Saez: Aquaculture, 37, 11-20 (1984).

5) J. D. Castell, E. G. Mason, and J. F. Covey: $J$. Fish. Res. Bd. Can., 32, 1431-1435 (1975).

6) L. R. D'Abramo, C. E. Bordner, D. E. Conklin, and N. A. Baum: Aquaculture, 42, 13-25 (1984).

7) A. Ponat and D. Adelung: Mar. Biol., 74, 275-
279 (1983).

8) S. Teshima and A. Kanazawa: Nippon Suisan Gakkaishi, 52, 1417-1422 (1986).

9) R. G. W. Steel and J. H. Torrie: Principle and Procedures of Statistics, 2nd ed., McGraw-Hill, New York, 1960, pp. 86-194.

10) D. A. Jones, A. Kanazawa, and S. Abdel Rahman: Aquaculture, 17, 33-43 (1979).

11) R. G.W. Steel and J. H. Torrie: Principle and Procedures of Statistics, 2nd ed., McGraw-Hill, New York, 1960, pp. 495-520.

12) A. Kanazawa and S. Teshima: Oceanolog. Acta, 1, 39-44 (1978).

13) M. Morisaki, H. Ohtaka, M. Okubayashi, and N. Ikekawa: J. Chem. Comm., 1275-1276 (1972).

14) N. Ikekawa, M. Morisaki, and Y. Fujimoto: Tanpakushitsu Kakusan Kohso, 28, 1304-1320 (1983).

15) S. Teshima and A. Kanazawa: Nippon Suisan Gakkaishi, 53, 601-607 (1987).

16) A. Kanazawa and S. Teshima: Nippon Suisan Gakkaishi, 37, 891-903 (1971).

17) J. B. Guary and A. Kanazawa: Comp. Biochem. Physiol., 54B, 205-208 (1976).

18) W. R. Nes and M. L. McKean: Biochemistry of Steroids and Other Isolprenoids, University Park Press, Baltimore, London, and Tokyo, 1977, pp. 535-629.

19) R. B. Clayton: J. Lipid Res., 5, 3-19 (1964).

20) J. A. Svoboda, M. J. Thompson, W. E. Robbins, and J. N. Kaplanis: Lipids, 13, 742-753 (1978). 